\title{
Prescription of anorectic and benzodiazepine drugs through notification B prescriptions in Natal, Rio Grande do Norte, Brazil
}

\author{
Solange Aparecida Nappo ${ }^{1}$, Elisaldo Araújo Carlini ${ }^{1, *}$, Maria Dalva Araújoº \\ Lúcio Flávio Sousa Moreira²
}

${ }^{1}$ Brazilian Information Center on Psychotropic Drugs, CEBRID, Department of Psychobiology, Federal University of São Paulo, ${ }^{2}$ Community Center, Brazilian Information Center on Psychotropic Drugs, CEBRID, Department of Social Sciences, Federal University of Rio Grande do Norte

\begin{abstract}
A study was conducted on 22,158 special B prescriptions (notificações B) containing amphetamine-type anorectic drugs or benzodiazepines, obtained from compounding pharmacies or drugstores located in the city of Natal, RN, Brazil. The data obtained were compared with those from other Brazilian cities. Results showed that compounding pharmacies dispensed $85.4 \%$ of the prescriptions, indicating that these pharmacies filled out nearly 10 times more of these prescriptions than did the drugstores. The majority $(83.5 \%)$ of B prescriptions issued for the compounding pharmacies were for women, where the female/male patient ratio ranged from 7.1/1.0 for mazindol to 10.3/1.0 for amfepramone. Similar results were obtained for the benzodiazepines with ratios of 1.9/1.0 for clonazepam to 15.6/1.0 for oxazepam. Omissions and mistakes were present in the B prescriptions, including missing information about the patient (in $49.6 \%$ of the documents) or about the pharmacies or drugstores $(50.4 \%)$. There were cases where the name and/or CRM of the physician was lacking. It was noted that one medical doctor made out 1855 B prescriptions within one year. The same patient's name appeared on 138 prescriptions, and the same RG (identification card number) was present in 125 others. Comparison of Natal's data with those of several other Brazilian cities disclosed a striking similarity throughout Brazil, from Pelotas Rio Grande do Sul State to Belem-Para State, revealing a practically identical medical/pharmaceutical behavior. This pattern of prescription/dispensation of amphetamine-type substances mostly to women for weight loss is therefore for cosmetic reasons. Consequently, there is an urgent need for an ethical review of this behavior.
\end{abstract}

Uniterms: Anorectic/prescription. Benzodiazepine/prescription. Obesity/treatment. Medicines/rational use. Compounded medicine. Compounding pharmacy.

Foram examinadas 22.158 notificações B contendo substâncias anoréticas tipo-anfetamina ou de benzodiazepínicos, obtidas de drogarias e de farmácias de manipulação. Os dados foram comparados com os de outras cidades do Brasil, obtendo-se uma visão nacional sobre o assunto. Os achados mostraram que as farmácias de manipulação, dispensaram $85,4 \%$ das notificações, ou seja, as farmácias de manipulação atenderam cerca de 10 vezes mais do que as drogarias. A maioria $(83,5 \%)$ das notificações B nas farmácias de manipulação eram destinadas às mulheres sendo a relação entre pacientes femininos/masculinos de 7,1/1,0 no caso do mazindol e de 10,3/1,0 para a anfepramona. Dados semelhantes foram obtidos para os benzodiazepínicos: relação de 1,9/1,0 para o clonazepam até 15,6/1,0 para o oxazepam. Falhas e erros gritantes foram também observados no preenchimento das notificações B: ausência de dados de pacientes (em 49,6\% dos documentos), do fornecedor (50,4\%) etc. Houve casos de notificações sem o nome ou CRM do médico e um único médico prescreveu 1.855 notificações B; o nome de uma mesma compradora apareceu em 138 notificações e um mesmo RG em 125 outras. A comparação destes achados com os de outras cidades mostrou uma surpreendente semelhança, ao longo do país, desde Pelotas-RS até Belém-PA; evidenciando um padrão de comportamento médico/farmacêutico praticamente idêntico.

\footnotetext{
*Correspondence: E. A. Carlini. Centro Brasileiro de Informações sobre Drogas Psicotrópicas - CEBRID, Departamento de Psicobiologia, Universidade Federal de São Paulo - UNIFESP. Rua Botucatu, 862 - São Paulo. E-mail: carlini@psicobio.epm.br
} 
Este padrão de prescrição para mulheres destina-se mais para uma finalidade cosmética (perda de peso) do que para uma real necessidade terapêutica. É necessária uma revisão ética sobre este problema, que também tem sido observado e igualmente criticado em vários países.

Unitermos: Anoréticos/prescrição. Benzodiazepínicos/prescrição. Obesidade. Medicamentos/uso racional. Fórmulas magistrais. Farmácia de manipulação.

\section{INTRODUCTION}

Much is known in Brazil about the increased use of amphetamine-type anorectic drugs (e.g., amfepramone, fenproporex and mazindol) combined with anxiolytic benzodiazepines, for the purpose of anorexia and consequent weight loss (Nappo, 1992, 1996); Nappo, Carlini, 1994; Nappo, Oliveira, Morosini, 1998; Noto et al., 2002; Santos et al., 2007). This use is made possible by a physician, through "Notifição B" prescriptions, as exacted by Ordinance 344/98 of ANVISA (Brazil's National Health Surveillance Agency); these prescriptions are stored in drugstores and compounding pharmacies for a minimum period of 2 years, allowing control of these dependenceinducing substances.

Besides the B prescriptions (retained by authorities), physicians may also prescribe several medicines for their patients in the form of a compounded formulation which is filled out in a compounding pharmacy (Nappo, 1996; Nappo, Oliveira, Morosini, 1998).

The purpose of a compounded medication is to provide a customized prescription, specific for each patient, with a dosage and combination of drugs that do not exist in manufactured medicines from the pharmaceutical industry and are not commercially available: This commonly occurs when compounded medications are intended for weight loss, where the compounded product can contain one or more anorectics, benzodiazepines, diuretics, laxatives, thyroid hormones, $\mathrm{KCl}$, or gonadotrophin etc.

It should be noted that benzodiazepines and anorectic amphetamines are also produced and sold as individual drugs under different commercial names (Nappo, Carlini, 1994).

The use of anorectic amphetamines for aesthetic purposes (weight loss) has been strongly criticized in various countries in Latin America (Instituto de Salud Pública de Chile, 1992; Boletim CEBRID, 1993), United States (Rothblum, 1994), Spain (Butlleti Groc, 1993) and England (Thomas, Campbell, 1996), as well as by the International Narcotics Control Board (INCB, 2005), an agency linked to the United Nations.

However, despite questions over the therapeutic utility and the awareness of the toxic potential of these am- phetamines (British National Formulary, 1994), the use of these drugs has risen unabated in many countries including Brazil. Thus, the INCB (2004) showed that in the 3-year periods of 1992 - 1994 and 2000 - 2002, the use of these drugs in Brazil was 7.40 and 6.78 DDDs (defined daily doses) per 1000 inhabitants, respectively, thus ranking the country second worldwide. Between 2002 and 2004, the use of these drugs in Brazil increased to 9.13 DDDs/1000 inhabitants (INCB, 2005), making it the world leader in this unfortunate "competition"

Scientific studies by Brazilian authors have shown that the use of anorectic amphetamines has occurred in cities located in various different Brazilian states: PelotasRio Grande do Sul State (Lima et al., 1998), São Paulo São Paulo State (Azzolini, 2003), São Caetano do Sul and Diadema - São Paulo State (Noto et al., 2002), Ribeirão Preto - São Paulo State (Andrade, Andrade, Santos, 2004), Belo Horizonte - Minas Gerais State (Carneiro, Guerra Jr, Acursio, 2008), Goiania - Goias State (Cunha et al., 2002), Fortaleza - Ceara State (Romeu, Justino, Lima, 2008), São Luiz - Maranhão State (Mariz, Silva, Ferreira et al., 2002) and Belém - Para State (Borges et al., 2008).

The aim of present work, in collaboration with the Health Surveillance Agency (VISA) of the State Secretariat for Health of Rio Grande do Norte State, Brazil, was to analyze the "Notificação B" prescriptions filled out by drugstores and compounding pharmacies in the city of Natal, and to extend the existing body of data on prescription of anorectic and anxiolytic drugs in Brazil by adding information on the State of Rio Grande do Norte.

\section{MATERIAL AND METHODS}

In 2002, 16 compounding pharmacies (establishments that can supply and sell compounded formulations containing controlled drugs) and 24 drugstores (cannot supply; but can sell finished controlled products) were randomly chosen, such that the different regions of Natal were equally represented. In both types of establishments, the preparations containing amphetamines and/or benzodiazepines can only be sold after presentation and submission of B prescriptions. These prescriptions for 2002 were collected by technicians from VISA for analysis. 
A computer program was specially developed to obtain and analyze the following data contained in the B prescriptions.

- $\quad$ name, stamp and CRM of physician;

- $\quad$ name and address of patient;

- $\quad$ name, address and telephone number of buyer;

- $\quad$ name of the medication, dose and number of units;

- Information on the drugstore or pharmacy.

The following records based on all the data gathered were obtained:

- $\quad$ omissions in filling out the B prescriptions by the physician and by the prescription-filling establishment;

- number of prescriptions per type of prescriptionfilling establishment;

- $\quad$ number of prescriptions by (and specialty of) physicians;

- $\quad$ substances prescribed and time of use;

- number of men and women to whom B prescriptions were issued.

\section{RESULTS}

\section{Number of prescriptions per type of prescription- filling establishment}

A total of 25,949 B prescriptions containing ano- rectic amphetamines or benzodiazepines were analyzed. These were collected from 16 compounding pharmacies and 24 drugstores. A total of 128 of the B prescriptions contained other types of substances and were not included.

As shown in Table I, 16 compounding pharmacies filled out 22,158 B prescriptions containing benzodiazepines or amphetamines ( $85.4 \%$ of the total), whereas 24 drugstores prepared only $3791 \mathrm{~B}$ prescriptions (14.6\% of the total). In other words, each compounding pharmacy handled, on average, 1385 prescriptions for psychotropic medications in 2002, almost 10 times the number handled by the corresponding drugstores in general (158 prescriptions prepared).

\section{Gender of Patients}

Table II shows that the vast majority ( $83.5 \%)$ of B notifications received by compounding pharmacies were prescribed for women where this was also the case for drugstores, albeit at a lower percentage (69.4\%).

\section{Errors/Omissions in filling out B prescriptions}

Of the total of 26,077 B prescriptions issued (including 128 notifications that did not contain benzodiazepines or amphetamines), a large number were filled out with omissions.

TABLE I - Number of B prescriptions received by compounding pharmacies and drugstores in 2002, in Natal, RN, Brazil

\begin{tabular}{llccc}
\hline Establishment & & Number of B prescriptions received & & $\begin{array}{c}\text { Number of B prescriptions/ } \\
\text { establishment }\end{array}$ \\
\hline type & $\mathrm{N}$ & $\mathrm{N}$ & $\%$ & 1385 \\
Compounding pharmacy & 16 & 22,158 & $85.4 \%$ & 158 \\
Drugstore & 24 & 3791 & $14.6 \%$ & -------- \\
Total & 40 & 25,949 & $100 \%$ & \\
\hline
\end{tabular}

* Only B prescriptions containing benzodiazepines or anorectic amphetamines were considered; 128 prescriptions containing other types of drugs were not considered.

TABLE II - Number of B prescriptions filled out for men and women in 2002 by compounding pharmacies ( $\mathrm{n}=16)$ and drugstores (24). Natal - RN

\begin{tabular}{lcccccc}
\hline \multirow{2}{*}{ Item } & \multicolumn{5}{c}{ Number of B prescriptions } \\
\cline { 2 - 7 } & \multicolumn{2}{c}{ Compounding pharmacy } & \multicolumn{2}{c}{ Drugstore } & \multicolumn{2}{c}{ Total } \\
\cline { 2 - 7 } & $\mathrm{N}$ & $\%$ & $\mathrm{~N}$ & $\%$ & $\mathrm{~N}$ & $\%$ \\
\hline Total B prescriptions & 22,158 & 100.0 & 3791 & 100.0 & $25,949^{*}$ & 100.0 \\
For women & 18,505 & 83.5 & 2632 & 69.4 & 21,137 & 81.4 \\
For men & 2907 & 13.1 & 935 & 24.6 & 3842 & 14.8 \\
Not identified & 746 & 3.4 & 224 & 6.0 & 970 & 3.8 \\
\hline
\end{tabular}

* Only B prescriptions containing benzodiazepines or anorectic amphetamines were considered; 128 prescriptions containing other types of drugs were not considered. 
These omissions occurred in practically all fields of the $\mathrm{B}$ prescription, particularly the address of the patients $(12,244=46.95 \%)$, the stamp of the supplier $(13,164=$ $50.48 \%)$ and information on the buyer $(1921=7.4 \%)$, where in the last field there were omissions of patient name (336 prescriptions), address (665 prescriptions) and/ or number of identification document (594 prescriptions). Various aberrant facts were found: in 35 B prescriptions the name of the patient was missing; the same person, a female, appeared as the buyer in 138 prescriptions and 10 other names appeared in 11 or more purchases. The same RG (ID) number appeared as the buyer in 125 prescriptions, where 9 other RG numbers appeared in 20 or more prescriptions.

More seriously, $181 \mathrm{~B}$ prescriptions were found without the physician's signature and/or stamp with the CRM number. Moreover, 10 physicians prescribed over $570 \mathrm{~B}$ prescriptions, where the leading health care professional prescribed 1855 B prescriptions in 2002. Finally, one patient was issued $46 \mathrm{~B}$ prescriptions and nine other patients received 14 or more in 2002.

\section{Substances prescribed}

Besides overseeing the use of amphetamine-type drugs and benzodiazepines, the B prescription notification scheme also serves to control the use of some barbiturates and anti-parkinsonian medication trihexyphenidyl (commercial product most utilized being Artane $\left.{ }^{\circledR}\right)$, among others. The number of prescriptions of these drugs was much smaller: 20 for barbiturates and 23 for trihexyphenidyl. However, a few B prescriptions were utilized for products that were not under the control of these special prescriptions, such as anabolic steroids (9 B prescriptions), antidepressants (20), antipsychotics (30), hypnotics (22) and anticonvulsants (4). In total, $128 \mathrm{~B}$ prescriptions were filled for these other substances.

Table III shows that women received the majority of prescriptions for anxiolytic medications: 10,143 out of a total of 13,420 or $75.6 \%$, where only $19.3 \%$ of B prescriptions were issued to male patients. Interestingly, $72.9 \%$ of the prescriptions for benzodiazepines were dispensed in 16 compounding pharmacies, while the remaining $27.1 \%$ were filled out by 24 drugstores. These numbers contrast with the $128 \mathrm{~B}$ notifications for prescriptions for other medications, for which both types of establishments dispensed practically the same numbers $(48.1 \%$ and $51.9 \%$, respectively). Table III shows that the most prescribed benzodiazepines in Natal, Rio Grande do Norte State in 2002 were diazepam (7009 B prescriptions) and chlordiazepoxide (2495). Again, it should be noted that women were overwhelmingly the ones for whom all benzodiazepines were prescribed, being from 2 times (clonazepam) to 16 times (oxazepam) more likely to receive these drugs than men.

Table IV shows that a total of $12,528 \mathrm{~B}$ prescriptions were for anorectic medications, where $87.8 \%$ were for women, i.e. 8.8 prescriptions for women for every prescription for men. These numbers are very close to those for prescriptions for the three amphetamine-type drugs

TABLE III - B prescriptions containing benzodiazepines, distributed by sex. Compounding pharmacies and drugstores were combined. Year, 2002. Natal - RN

\begin{tabular}{|c|c|c|c|c|c|c|c|c|c|}
\hline \multirow{4}{*}{ Drug } & \multicolumn{8}{|c|}{ Number of B prescriptions } & \multirow{4}{*}{$\begin{array}{c}\text { Ratio } \\
\text { Female/ } \\
\text { Male }\end{array}$} \\
\hline & & & & & & & & & \\
\hline & \multicolumn{2}{|c|}{ Total } & \multicolumn{2}{|c|}{ Female } & \multicolumn{2}{|c|}{ Male } & \multicolumn{2}{|c|}{ Not identified } & \\
\hline & $\mathrm{N}$ & $\%$ & $\mathrm{~N}$ & $\%$ & $\mathrm{~N}$ & $\%$ & $\mathrm{~N}$ & $\%$ & \\
\hline All benzodiazepines & 13,420 & 100 & 10,146 & 75.6 & 2596 & 19.3 & 678 & - & 3.91 \\
\hline Diazepam & 7009 & 100 & 5572 & 79.5 & 1124 & 16.0 & 313 & - & 4.95 \\
\hline Chlordiazepoxide & 2495 & 100 & 1884 & 75.5 & 511 & 20.4 & 100 & - & 3.68 \\
\hline Bromazepam & 750 & 100 & 580 & 77.3 & 123 & 16.4 & 47 & - & 4.71 \\
\hline Cloxazolam & 748 & 100 & 541 & 72.3 & 154 & 20.6 & 53 & - & 3.51 \\
\hline Clonazepam & 714 & 100 & 433 & 60.6 & 221 & 30.9 & 60 & - & 1.95 \\
\hline Lorazepam & 493 & 100 & 343 & 69.5 & 119 & 24.1 & 31 & - & 2.88 \\
\hline Oxazepam & 239 & 100 & 219 & 89.9 & 14 & 5.8 & 6 & - & 15.64 \\
\hline Others* & 972 & 100 & - & - & - & - & - & - & - \\
\hline
\end{tabular}

*Camazepam, Flunitrazepam, Fludiazepam, Clorazepam, Estazolam, Flurazepam, Nitrazepam, Midazolam, Clobazam and Alprazolam. 
TABLE IV - B prescriptions containing amphetamine-type drugs, distributed by sex. Compounding pharmacies and drugstores were combined in general. Year, 2002. Natal - RN

\begin{tabular}{|c|c|c|c|c|c|c|c|c|c|}
\hline \multirow[t]{4}{*}{ Dru } & \multicolumn{8}{|c|}{ Number of B prescriptions } & \multirow{4}{*}{$\begin{array}{c}\text { Ratio } \\
\text { Female/ } \\
\text { Male }\end{array}$} \\
\hline & & & & & & & & & \\
\hline & \multicolumn{2}{|c|}{ Total } & \multicolumn{2}{|c|}{ Female } & \multicolumn{2}{|c|}{ Male } & \multicolumn{2}{|c|}{ Not identified } & \\
\hline & $\mathrm{N}$ & $\%$ & $\mathrm{~N}$ & $\%$ & $\mathrm{~N}$ & $\%$ & $\mathrm{~N}$ & $\%$ & \\
\hline All & 12,528 & 100 & 10,992 & 87.8 & 1244 & 9.9 & 292 & 2.3 & $8.8 / 1$ \\
\hline Amfepramone & 610 & 100 & 5413 & 88.7 & 523 & 8.2 & 164 & 3.1 & $10.3 / 1$ \\
\hline Fenproporex & 4475 & 100 & 3929 & 87.8 & 455 & 10.2 & 91 & 2.0 & $8.6 / 1$ \\
\hline Mazindol & 1952 & 100 & 1675 & 85.8 & 237 & 12.1 & 40 & 2.1 & $7.1 / 1$ \\
\hline Phendimetrazine* & 1 & - & - & - & - & - & - & - & - \\
\hline
\end{tabular}

*Drug not licensed in Brazil.

amfepramone, fenproporex and mazindol, when analyzed separately.

\section{DISCUSSION}

The present study showed that the supply and dispensation of prescriptions containing amphetamine-type drugs, combined with benzodiazepines and other drugs or otherwise, is a very commonplace practice in Natal - Rio Grande do Norte State. This practice occurs predominantly in compounding pharmacies which were responsible for $85 \%$ of the total supply. These drugs were practically always in the form of compounded formulations in combination with a large number of different substances. Thus, what occurs in various cities throughout Brazil in the states of Rio Grande do Sul, São Paulo, Goias, Maranhão, Minas Gerais, Ceará and Pará, i.e., the prescription and supply of medications for the purpose of weight loss, appears to be a medical-pharmaceutical practice of national proportion, covering all the major population regions of the country. Furthermore, in spite of the warnings issued by Brazilian and International Authorities this unreasonable prescription/dispensation practice seems to continue unabated over time and geography.

Thus, in Natal, as shown in the present study, women were the most frequent recipients of prescriptions of anorectics, receiving $87.8 \%$ of the total issued. In Belo Horizonte, $88 \%$ of the anorectics dispensed in 2003 were prescribed to women (Carneiro et al., 2008). A similar figure (86\%) was detected for Belem in 2006 (Borges et al., 2008) and in Goiania (87\%) between 2003 and 2004 (Santos et al., 2007). In Fortaleza, women were also found to be the main users $(74.5 \%)$ of anorectic medicaments in 2005 (Romeu et al., 2008).

Also, coincident among the prescriptions of different cities, is the high number of irregularities, such as the lack of the address of the patient, identification (stamp) of the supplier, name of the buyer, signature and/or CRM of the physician, etc, revealing a generalized negligence in Brazil in the regulation of internationally controlled substances which are restricted due to their dependence-inducing capacity. Since 1988, the International Narcotics Control Board (INCB 1989) has repeatedly warned Brazil about the exaggerated use of anorectic amphetamines. In 2008, the UN-linked agency stressed: "131. Consumption of stimulants in Schedule IV continued to increase significantly in some countries in the Americas, such as Argentina, Brazil and United States... 132. The Board reiterates its appeal to Governments ... to monitor their trend of use..." (INCB, 2007).

Fortunately, the situation appears to have finally attracted attention: Brazil's National Health Surveillance Agency (ANVISA, 2007) established the National System for the Management of Controlled Products (SNGPC) which imposes stricter control of the prescription and dispensation of benzodiazepines and anorectic amphetamines. Portugal, a country suffering from similar problems, has resolved the situation through an ordinance from the Ministry of Health, prohibiting the prescription and preparation of compounded formulations containing anorectic amphetamines (Portugal, Ministry of Health, 1999).

However, examination of the data of the present study and that of other studies on the use of anorectic drugs for the treatment of overweight reveals an ethical problem. Nappo et al. (2001) investigated the use of anorectics in more than 2000 patients from São Paulo and Brasilia, and in consonance with international studies, suggested that these drugs are used more for cosmetic reasons (due to a culture of being thin as a symbol of beauty) than for therapeutic reasons, thus not justifying their indiscriminate use.

Finally, various other authors have raised doubts over the ethics of the treatment of overweight with ano- 
rectic agents (Pace, Bolton, Reeves, 1991; Lustig, 1991; Begley, 1991; Wooley, Garner, 1991; Germov, Williams, Wright, 1995, 1996; Reidenberg, 2000).

\section{REFERENCES}

ANDRADE, M. F.; ANDRADE, R. C. G.; SANTOS, V. Prescrição de psicotrópicos: avaliação das informações contidas em receitas e notificações. Rev. Bras. Ciênc. Farmac., v.40, n.4, p.471-479, 2004.

AZZOLINI, C. A. Perfil das substâncias e medicamentos sujeitos a controle especial, dispensados nas drogarias e farmácias dos municípios da jurisdição da DIR IV. Infarma, v.15, n.11, p.75-78, 2003.

BEGLEY, C. E. Government should strengthen regulation in the weight loss industry. J. Am. Diet. Assoc., v.91, n.10, p.1255-1257, 1991.

BOLETIM CEBRID. Centro Brasileiro de Informações sobre Drogas Psicotrópicas. Item 13: Países sul-americanos solicitam legislação proibindo fórmulas magistrais e associações medicamentosas para tratamento de obesidade. São Paulo, 1993. n.12, p.5.

BORGES, G. P. M.; BELO, T.; VIEIRA, G. M. M.; VIEIRA, J. R. $\mathrm{S}$. Análise dos receituários de medicamentos psicotrópicos anorexígenos em uma rede privada de farmácia de Belém - Pará. Infarma, v.20, n.9/10, p.26-30, 2008.

BRITISH NATIONAL FORMULARY. Centrally acting appetite stimulants. London: British Medical Association and Royal Pharmaceutical Society of Great Britain, 1994. n.28, p.173.

BUTLLETI GROC. Institut Català de Farmacologia. Los riesgos de los tratamientos farmacológicos de la obesidad. Barcelona, v.6, n.4, p.13-14, 1993.

CARNEIRO, M. F. G.; GUERRA JR, A. A.; ACURSIO, F. A. Prescrição, dispensação e regulação do consumo de psicotrópicos anorexígenos em Belo Horizonte, Minas Gerais, Brazil. Cad. Saúde Pública, v.24, n.8, p.1763-1772, 2008.

CUNHA, L. C.; AZEREDO, F. S.; GUIMARÃES, R. I.; PAULA, J. R. Análise e avaliação crítica da incidência de fármacos anorexígenos sintéticos em "produtos naturais" para emagrecimento em Goiânia - GO. Rev. Bras. Toxicol., v.15, n.2, p.69-72, 2002.
GERMOV, J.; WILLIAMS, L. The epidemic of dieting women: the need for a sociological approach to food and nutrition. Appetite, v.27, p.97-108, 1996.

INTERNATIONAL NARCOTICS CONTROL BOARD. INCB. Statistics on Psychotropic Substances for 1988 Vienna, E/ INCB/1989/3, 1989. p. vii.

INTERNATIONAL NARCOTICS CONTROL BOARD. INCB. Schedule IV amphetamine type stimulants used as anorectics. Document E/INCB/2004/W.2/SS.3. Vienna, 2004. p.7.

INTERNATIONAL NARCOTICS CONTROL BOARD. INCB. Stimulants in schedule IV of the 1971. Convention used as anorectics. Rep. Int. Narc. Control Board. Vienna, 2005. p.26.

INTERNATIONAL NARCOTICS CONTROL BOARD. INCB. Schedule IV amphetamine type stimulants used as anorectics. United Nations Publications $\mathrm{n}^{\circ} \mathrm{E} /$ INCB/2004/W.2/SS.3 and E/INCB/2005/W.5. Vienna, 2005. p.27-30.

INTERNATIONAL NARCOTICS CONTROLBOARD. INCB. Consumption of psychotropic substances. Rep. Int. Narc. Control Board. Vienna, 2007. p. 26, item 131-132.

INSTITUTO DE SALUD PUBLICA DE CHILE. La peligrosa moda de las formulas antiobesidad. Boletim de Informações de Medicamentos. Santiago, 1992. v.6, p.13-15.

LIMA, M. S.; BERIA, J. V.; TOMASI, E. L.; MARI, J. J. Use of amphetamine-like appetite suppressants: a cross-sectional survey in southern Brazil. Subst. Use Misuse, v.33, n.8, p.1711-1719, 1998.

LUSTIG, A. Weight loss programs: failing to meet ethical standards? J. Am. Diet. Assoc., v.91, n.10, p.1252-1254, 1991.

MARIZ, S. R.; SILVA, R. M. A.; FERREIRA, J. C.; MORAES, O. K. D.; SILVEIRA, L. M. S. Avaliação preliminar da dispensação de anorexígenos em São Luis- Maranhão. Infarma, v.14, n.9/10, p.56-60, 2002.

PORTUGAL. Ministério da Saúde. Gabinete do Secretário do Estado da Saúde. Diário da República. 12 de março, 1999. II Serie, n.60, p. 3696(2). 
NAPPO, S. A. Consumo de anorexígenos tipo-anfetamina (dietilpropiona, fenproporex, mazindol) e de fenfluramina no Brasil: prejuízo ou benefício para a Saúde. J. Bras. Psiquiatr., v.41, n.8, p.417-421, 1992.

NAPPO, S. A. Consumption of anorexigenic amphetamine-like drugs (diethylpropion, fenproporex and mazindol) and d,1fenfluramine in Brazil during the years of 1988 and 1989. Pharmacoepidemiol. Drug Saf., v.5, n.1, p.19-25, 1996.

NAPPO, S. A.; CARLINI, E. A. Anoréticos: situação atual no Brasil. Arq. Bras. Endocrinol. Metab., v.38, n.2, p.69-75, 1994.

NAPPO, S. A.; OLIVEIRA, E. M.; MOROSINI, S. Inappropriate prescribing of compounded antiobesity formulas in Brazil. Pharmacoepidemiol. Drug Saf., v.7, n.3, p.207-212, 1998.

NAPPO, S. A.; TABACH, R.; NOTO, A. R.; CARLINI, E. A. Use of anorectic amphetamine-like drugs by Brazilian women. Eat. Behav., v.3, n.2, p.153-165, 2002.

NOTO, A. R.; CARLini, E. A.; MASTROIANNI, P. C.; ALVES, V. C. GALDUROZ, J. C. F.; KUROIWA, W.; CSIZMAR, J.; COSTA, A.; FARIA, M. A.; HIDALGO, S. R.; ASSIS, D.; NAPPO, S. A. Analysis of prescription and dispensation of psychotropic medications in two cities in state of São Paulo. Rev. Bras. Psiquiat., v.24, n.2, p.68-73, 2002.

PACE, P. W.; BOLTON, M. P.; REEVES, R. S. Ethics of obesity treatment implications for dietitians. J. Am. Diet. Assoc., v.91, n.10, p.1358-1360, 1991.
REIDENBERG, M. M. Are we treating health or physical appearance when we prescribe drugs for obesity? Int. J. Clin. Pharmacol. Ther., v.67, n.3, p.193-195, 2000.

ROMEU, G. A.; JUSTINO, P. S. C.; LIMA, A. M. A. Perfil da prescrição e dispensação de fármacos anorexígenos em Fortaleza - CE. Infarma, v.20, n.7, p.32-37, 2008.

ROTHBLUM, E. D. I will die for the revolution but don't ask me not to diet: feminism and the continuing stigmatization of obesity. In: FALLON, P.; KATZMAN, M.A.; WOOLEY, S.C. (Eds.). Feminist perspective in eating disorders. New York: Geulford Press, 1994. p.53-76.

SANTOS, E. N.; NUNES, J. R. L.; ROCHA, D. L.; SOUZA, M. L.; RIBEIRO, V. P.; REED, E.; SILVA, L. M.; BARBOSA, V. S.; GUERRA, F. C. Avaliação do consumo de anorexigenos em farmácias de manipulação, Goiania GO. Infarma, v.19, n.1/2, p.17-19, 2007.

THOMAS, S. H. L.; CAMPBELL, M. Utilization of appetite suppressants in London: a putative indication of poor prescribing practice. Pharmacoepidemiol. Drug Saf., v.5, n. 4, p.237-246, 1996.

WRIGHT, J. D. Triumph of obesity or of human insanity. Lancet, v.346, sep.2, p.636-637, 1995.

WOOLEY, S. C.; GARNER, D. M. Obesity treatment: the high cost of false hope. J. Am. Diet. Assoc., v.91, n.10, p.12481251,1991 .

Received for publication on $17^{\text {th }}$ June 2009 Accepted for publication on $11^{\text {th }}$ October 2009 